\title{
GENDER DALAM BAHASA SAMAWA TINJAUAN ANTROPOLINGUISTIK
}

\author{
Jumianti Diana', Mahsun ${ }^{2}$, \& Burhanuddin ${ }^{3}$ \\ Magister Pendidikan Bahasa Indonesia, Universitas Mataram \\ Surel: arkandiana@gmail.com
}

\begin{abstract}
Abstrak
Penelitian ini bertujuan untuk mengungkapkan wujud kebahasaan yang mencerminkan gender dalam bahasa Samawa dengan menggunakan teori antropolinguistik. Pengumpulan data dalam penelitian ini menggunakan metode wawancara atau cakap, metode simak atau metode catat dan metode introspeksi. Hasil penelitian menunjukkan adanya kata, gabungan kata, istilah, ungkapan dan tradisi dalam masyarakat Samawa yang berperspektif gender. Berdasarkan hasil penelitian tersebut dapat dikemukakan tentang perempuan Samawa sangat dihargai kedudukannya oleh masyarakatnya. Sikap dan perlakuan serta pandangan masyarakat Samawa lebih menyadari dan memahami tentang kesetaraan gender.
\end{abstract}

Kata Kunci: Gender, Bahasa Samawa dan Antropolinguistik.

\section{A. PENDAHULUAN}

Indonesia merupakan negara yang memiliki aneka ragam suku dan memiliki bahasa daerah yang beragam pula. Adanya keanekaragaman suku dan bahasa daerah di Indonesia membuat masyarakat Indonesia menggunakan bahasa Indonesia sebagai bahasa persatuan. Keanekaragaman itu tercermin dalam suku di Provinsi Nusa Tenggara Barat. Di Provinsi Nusa Tenggara Barat setidaknya terdapat tiga etnis atau suku mayoritas, yaitu suku Sasak, suku Samawa dan suku Mbojo. Ketiga suku tersebut menggunakan bahasa daerah yang berbeda-beda, yaitu suku Sasak menggunakan bahasa Sasak, suku Samawa menggunakan bahasa Samawa, dan suku Mbojo menggunakan bahasa Mbojo.

Masyarakat suku Samawa menempati pulau Sumbawa bagian barat yang secara administratif termasuk dalam kabupaten Sumbawa dan kabupaten Sumbawa Barat. Seperti diketahui, bahasa termasuk bahasa Samawa merupakan lambang sekaligus cerminan identitas penuturnya. Selain itu, bahasa Samawa juga 
mencerminkan tentang cara pandang atau cara pikir penuturnya. Sebagaimana dikemukakan oleh Sapir-Whorf (dalam Yunhadi, 2016:169) bahwa "bahasa berpengaruh terhadap cara berpikir warga masyarakat, membentuk kebudayaan masyarakat dan penentu pokok wujud-wujud kebudayaan”. Cara pandang diekspresikan dalam bahasa dan bahasa dapat pula mendeskripsikan budaya masyarakat pengguna bahasa tersebut. Cara pikir atau cara pandang masyarakat terhadap dunia ditentukan oleh struktur bahasa. Cara pandang tersebut dapat melingkupi banyak aspek kehidupan sosial masyarakat tersebut, termasuk aspek gender.

Dalam bahasa Samawa ditemukan beberapa konsep yang berupa leksikon, istilah, maupun ungkapan dan tradisi-tradisi yang berkaitan dengan gender. Misalnya, dalam ungkapan ramoa sawai dapat diartikan bermulut perempuan atau cerewet seperti perempuan. Hal tersebut menunjukkan bahwa sifat ramoa merupakan sifat yang dilekatkan pada perempuan sehingga ketika ada laki-laki yang cerewet maka laki-laki tersebut akan diidentikkan dengan perempuan.

Bagaimana bentuk leksikon, ungkapan dan tradisi yang menjelaskan tentang gender belum teridentifikasi secara mendasar. Oleh karena itu, penelitian bahasa Samawa untuk mengungkapkan wujud kebahasaan yang mencerminkan gender.

\section{B. KAJIAN TEORI}

Jika membahas tentang gender maka harus dipahami tentang konsep seks (jenis kelamin) karena gender berbeda dengan jenis kelamin (seks). Menurut Fakih (2013:7-9) seks (jenis kelamin) merupakan penyifatan atau pembagian dua jenis kelamin manusia yang ditentukan secara biologis yang melekat pada jenis kelamin tertentu yang bersifat kodrati, sedangkan gender merupakan konstruksi secara sosial dan kultural. Konsep tersebut senada dengan yang dikemukakan oleh Mahmud (2009:21). Demikian pula ditegaskan oleh Iswary (2009:115) bahwa gender dapat berarti sebagai peran dan tanggung jawab yang digagaskan secara 
sosial yang diberikan kepada kaum perempuan dan laki-laki dalam suatu kebudayaan atau lokasi tertentu yang didukung oleh struktur-struktur masyarakat.

Secara substansi studi ini termasuk dalam ranah antropolinguistik (bahasa dan budaya) sebagaimana dikemukakan oleh Sibarani (2004:50) bahwa antropolinguistik adalah cabang linguistik yang mempelajari variasi dan penggunaan bahasa dalam hubungannya dengan perkembangan waktu, perbedaan tempat komunikasi, sistem kekerabatan, pengaruh kebiasaan etnik, kepercayaan, etika berbahasa, adat istiadat dan pola-pola kebudayaan lain dari suatu suku bangsa. Foley (2001:3) mengemukakan bahwa linguistik antropologi memandang bahasa melalui prisma konsep antropologi inti, yakni budaya, dengan berusaha mencari "makna" (meaning) di balik penggunaan (use), kesalahpenggunaan (misuse), dan ketidakpenggunaan (non-use) bahasa, bentuknya yang berbeda, register dan gayanya.

Kramsch (dalam Iswary, 2009:114-115) mengemukakan tentang hubungan bahasa dan budaya, yaitu (1) Bahasa mengekspresikan realitas kultural yang berarti kata-kata yang diujarkan berhubungan dengan pengalaman. Katakata mengekspresikan fakta, ide, peristiwa yang dapat diteruskan karena berhubungan dengan pengetahuan tentang dunia; (2) bahasa menambah realitas kultural yang berarti bahwa anggota-anggota masyarakat atau kelompokkelompok sosial tidak hanya mengekspresikan pengalaman, tetapi mereka juga menciptakan pengalaman melalui bahasa; (3) bahasa menyimbolisasikan realitas kultural bahwa bahasa merupakan sistem tanda-tanda yang mempunyai nilai kultural. Para penutur mengidentifikasikan diri mereka sendiri dan orang lain melalui penggunaan bahasa. Hermansyah (2017:22) mengemukakan bahwa bahasa dan budaya saling memengaruhi, saling mengisi dan dapat berjalan berdampingan. Bahasa adalah bagian dari kebudayaan sehingga mempelajari suatu bahasa secara tidak langsung juga mempelajari kebudayaan, sehingga bahasa harus dipelajari dalam konteks kebudayaan dan sebaliknya, kebudayaan dapat dipelajari melalui bahasa.

Ada tiga konsep penting dalam antropologi linguistik yang dikemukakan oleh Duranti (1997:14-21) yaitu performansi (performance), indeksikalitas 
(indexicality), dan partisipasi (participation). Duranti (dalam Sibarani, 2015:3) menjelaskan bahwa melalui performansi bahasa dipahami dalam proses kegiatan, tindakan dan pertunjukan komunikatif yang membutuhkan kreativitas. Bahasa sebagai unsur lingual yang menyimpan sumber-sumber kultural tidak dapat dipahami secara terpisah dari kegiatan berbahasa. Konsep indeksikalitas berasal dari pemikiran filosof Amerika Charles Sanders Peirce yang membedakan tanda atas tiga jenis yakni indeks, simbol dan ikon. Indeks adalah tanda yang mengindikasikan bahwa ada hubungan alamiah dan eksistensial antara menandai dan yang ditandai. Konsep indeksikalitas diterapkan pada ekspresi linguistik seperti pronomina demonstratif, pronomina diri, adverbia waktu dan adverbia tempat. Adapun konsep partisipasi memandang bahasa sebagai aktivitas sosial yang melibatkan pembicara dan pendengar sebagai pelaku sosial.

Adapun konteks budaya yang akan difokuskan dalam penelitian ini adalah keseluruhan cara pandang masyarakat suku Samawa yang termanifestasi dalam sistem tingkah laku (termasuk cara berpikir, bertindak, dan berinteraksi). Cara pandang masyarakat yang mengandung gender di dalam bahasa yang digunakan oleh masyarakat suku Samawa. Kajian antropolinguistik di dalam penelitian ini dimanfaatkan untuk melihat budaya masyarakat suku Samawa melalui bahasa yang digunakan dalam masyarakat.

\section{METODE PENELITIAN}

Data dalam penelitian ini dikumpulkan dari penutur bahasa Samawa Dialek Samawa Rea yang tinggal di kecamatan Moyo Hilir dan kota Sumbawa Besar, Kabupaten Sumbawa. Data kebahasaan yang dikumpulkan berupa leksikon, istilah, ungkapan dan tradisi yang berperspektif gender. Data-data tersebut dikumpulkan secara langsung di lapangan (data primer) dan dari berbagai kepustakaan (data sekunder). Kaitannya dengan hal tersebut, pengumpulan data dalam penelitian ini menggunakan metode wawancara atau cakap, metode simak atau metode catat dan metode introspeksi. Metode wawancara digunakan untuk mengetahui bentuk kebahasaan (leksikon, istilah, ungkapan dan tradisi berupa data primer dengan teknik catat. Metode simak atau observasi juga digunakan 
dengan tujuan yang sama dengan metode wawancara. Hanya saja, bentuk kebahasaan berupa leksikon, istilah, ungkapan dan tradisi diperoleh melalui pengamatan terhadap penutur bahasa Samawa dialek Samawa Rea dan literatur atau bahan kepustakaan. Adapun metode introspeksi digunakan untuk mengumpulkan data dan memverifikasi data.

Metode yang akan digunakan dalam menganalisis data adalah metode padan intralingual dan metode padan ekstralingual. Metode padan intralingual adalah metode analisis dengan cara menghubung-bandingkan unsur-unsur yang bersifat lingual, baik yang terdapat dalam satu bahasa maupun dalam beberapa bahasa yang berbeda. Metode padan ekstralingual adalah metode yang digunakan untuk menganalisis unsur yang bersifat ekstralingual seperti menghubungkan masalah bahasa dengan hal yang berada di luar bahasa (Mahsun, 2017:120-123). Jadi, metode padan ekstralingual ini digunakan oleh peneliti untuk menganalisis nilai-nilai kultural yang terkandung dalam leksikon, istilah, ungkapan dan tradisi masyarakat Samawa.

\section{PEMBAHASAN}

Bahasa Samawa membedakan jenis kelamin dengan sebutan sawai 'perempuan' dan salaki 'laki-laki'. Untuk menyebut anak gadis dengan sebutan dadara dan menyebut jejaka dengan sebutan taruna. Hasil penelitian menunjukkan bahwa terdapat kata, gabungan kata, istilah, ungkapan dan beberapa tradisi yang mencerminkan gender dalam bahasa Samawa.

\section{a. Kata dan Gabungan Kata Berperspektif Gender}

Hasil penelitian ditemukan bentuk berupa kata dan gabungan kata yang berperspektif gender, yaitu ina-bapak; sanak sawai-salaki (sanak sawai-sanak salaki); adi-kakak; nya ta; tode ta; siya, [k(a)kak], kelam; saya, kaji, kajulin; dan basawai, basalaki.

Jika dalam bahasa Indonesia sering didengar kata bapak-ibu, saudarasaudari maka di dalam bahasa Samawa seringkali disebutkan ibu atau perempuan terlebih dahulu, seperti dalam kata ina-bapak 'ibu-bapak'. Konsep ina-bapak 
dalam bahasa Samawa digunakan dalam memulai pengumuman dan sambutansambutan dalam acara sorong serah maupun acara ta'siah. Seperti halnya konsep ina-bapak, konsep sanak sawai-salaki 'saudari-saudara' juga digunakan dalam pengumuman maupun sambutan. Konsep sanak sawai-salaki merupakan kata-kata kedua yang digunakan setelah kata ina-bapak saat memberikan pengumuman maupun sambutan. Hal tersebut menunjukkan bahwa masyarakat suku Samawa memandang bahwa ibu atau perempuan adalah orang yang sangat berharga dan sangat dihormati sehingga siapapun yang sedang berbicara saat memberikan sambutan ataupun memberikan pengumuman maka kata ina dan kata sanak sawai akan selalu menjadi kata yang diucapkan terlebih dahulu. Sehingga dapat dipahami bahwa masyarakat suku Samawa selalu mendahulukan perempuan dalam pembicaraan maupun dalam perlakuannya. Melalui bahasa tersebut menunjukkan bahwa laki-laki Samawa sangat menghargai perempuan dan mendahulukannya.

Konsep adi-kakak 'adik-kakak' menunjukkan bahwa adik identik dengan perempuan karena laki-laki dalam penutur bahasa Samawa sering memanggil perempuan dengan sebutan adik. Contohnya, di dalam rumah tangga, biasanya laki-laki yang menjadi suami sering memanggil adi 'adik' pada istrinya. Contoh lainnya, seorang jejaka berpapasan di jalan dengan seorang gadis, maka jejaka tersebut akan menyapa gadis tersebut dengan sebutan adi. Oleh karena itu, di dalam percakapan yang berupa sambutan dalam sebuah kegiatan dalam bahasa Samawa adi disebut terlebih dahulu daripada kakak karena sebutan adi itu identik dengan panggilan laki-laki kepada perempuan. Hal tersebut menunjukkan bahwa masyarakat suku Samawa sangat menghormati perempuan.

Konsep gender nya ta 'orang ini' digunakan oleh penutur laki-laki ke laki-laki lain yang sebaya atau lebih kecil usianya, sedangkan konsep tode ta 'anak ini' digunakan oleh penutur laki-laki dan perempuan ke perempuan yang lebih kecil. Selain itu, konsep tode ta dapat juga digunakan oleh seorang ibu atau perempuan kepada anak laki-laki. Misalnya, seorang ibu mengatakan tode ta kepada anak laki-lakinya. Jadi, konsep nya ta hanya digunakan oleh laki-laki 
untuk laki-laki, sedangkan konsep tode ta lebih sering digunakan untuk perempuan dan anak kecil baik perempuan maupun laki-laki.

Penggunaan kata siya artinya 'kamu' (hormat); $[k(a) k a k]$ memiliki variasi kakak, akak dan kak 'kakak'; dan kelam 'kamu' (mengekspresikan penghormatan terhadap bangsawan, orang bergelar haji dan hajah, tokoh masyarakat dan tokoh agama). Penggunaan kata-kata tersebut untuk mengekspresikan penghormatan kepada lawan bicara yang lebih tua dari si pembicara baik laki-laki maupun perempuan. Kata yang digunakan oleh pembicara seperti kata saya, kaji dan kajulin artinya 'aku' (digunakan oleh orang pertama tunggal kepada pendengar yang dituakan). Perkataan tersebut dapat digunakan oleh lelaki terhadap perempuan yang lebih tua atau dapat pula digunakan oleh perempuan terhadap laki-laki yang dituakan.

Adapun basawai 'menikah' (bagi laki-laki) dan basalaki 'menikah' (bagi perempuan). Konsep basawai digunakan untuk lelaki yang sudah menikah, seperti dalam contoh kalimat kamo basawai anakku artinya anakku (lelaki) sudah menikah atau anak laki-lakiku sudah menikah. Demikian pula pada kalimat kamo basalaki anakku artinya anakku (perempuan) sudah menikah atau anak perempuanku sudah menikah. Konsep basawai dan basalaki merupakan dikotomi yang berperspektif gender dalam bahasa Samawa.

\section{b. Istilah Berperspektif Gender}

Hasil penelitian ditemukan istilah berperspektif gender dalam bahasa Samawa, yaitu tete sawai 'tangga perempuan'; lawang sawai 'pintu perempuan' dan lunyuk emas 'tempat musyawarah bagi perempuan'. Istilah tete sawai berarti tangga perempuan atau tangga yang terletak di bagian belakang rumah dan khusus digunakan oleh perempuan untuk naik dan turun rumah. Istilah tete sawai seperti yang dikonsepsikan oleh Hermansyah (2017:57) sebagai tangga belakang bala (rumah adat) yang digunakan untuk membawa makanan naik atau turun ke Istana. Biasa disebut demikian karena tangga tersebut khusus untuk perempuan.

Selain istilah tete sawai, juga ditemukan istilah lawang sawai 'pintu perempuan'. Konsep lawang sawai mirip dengan tete sawai, yaitu pintu yang 
digunakan khusus untuk kaum perempuan terletak di belakang sehingga biasa disebut pintu belakang. Lawang sawai merupakan pintu yang digunakan oleh perempuan untuk keluar masuk rumah jika di ruang tamunya sedang ada tamu sehingga mereka tidak akan mengganggu tamunya saat keluar masuk rumah untuk menyiapkan berbagai keperluan. Lawang Sawai terletak lebih dekat dengan dapur, sehingga perempuan akan dengan mudah keluar masuk.

Adapun istilah lunyuk emas, oleh Hermansyah (2017:52-53) dikonsepsikan sebagai sesuatu yang bertalian dengan perempuan, yaitu sebagai sosok yang berharga. Konsep emas pada bentuk lunyuk emas sangat sesuai dengan nilai-nilai tentang keperempuanan, misalnya perempuan dianggap sebagai sesuatu yang berharga, berkilau, perhiasan (karena kecantikannya) dan didambakan. Konsep ini bertalian dengan tokoh Lala Jinis (tokoh dalam cerita rakyat Samawa) yang diidealkan masyarakat Samawa yang memiliki sifat atau nilai-nilai perjuangan, martabat dan kepedulian antarsesama. Secara historis dalam kepemimpinan kesultanan Sumbawa sangat mengakui peran dan eksistensi perempuan. Keberadaan bentuk terminologi lunyuk emas sebagai tempat musyawarah khusus perempuan.

\section{c. Ungkapan berperspektif gender}

Ungkapan dalam bahasa Samawa disebut ama Samawa. Ama Samawa merupakan bentuk pengungkapan pesan bersifat simbolik yang digunakan oleh masyarakat Samawa dalam berkomunikasi. Pengungkapan melalui simbol-simbol tersebut lebih menonjolkan maknanya. Hasil penelitian ditemukan adanya ungkapan berperspektif gender dalam bahasa Samawa, yaitu ramoa sawai 'bermulut perempuan' (cerewet); tau mbale ‘orang rumah' (pasangan); tau sawai nti pamongka, tau salaki nti rangala 'perempuan memegang periuk nasi, laki-laki memegang alat bajak sawah'; tau salaki balemar, tau sawai basoan 'laki-laki memikul di pundak, perempuan menjunjung'; basawai dunung sanopoka basawai 'menikah dulu sebelum menikah'; berang uda api 'parang yang kurang tajam/kurang matang saat di api'; dan mara bulan kapangan 'bagaikan gerhana bulan'. 
Ungkapan ramoa sawai 'bermulut perempuan' (cerewet). Hal tersebut menunjukkan bahwa cerewet adalah sifat yang diidentikkan dengan perempuan sehingga jika ada laki-laki yang cerewet, maka akan diidentikkan dengan perempuan atau dicap sebagai laki-laki yang bermulut perempuan. Jadi, cerewet merupakan stereotipe perempuan di dalam masyarakat Samawa.

Ungkapan tau mbale 'orang rumah' (dimaksudkan dengan pasangan seseorang baik istri maupun suami). Sebuah kalimat tanya sebagai contoh dalam bahasa Samawa untuk menanyakan tentang pasangan dari lawan bicara adalah Sai singin tau mbalemu? (Siapa nama orang rumahmu?). Orang rumahmu maksudnya adalah pasanganmu, yaitu suami atau istri. Pertanyaan tersebut ditanyakan kepada seorang laki-laki untuk menanyakan nama istrinya atau pada perempuan untuk menanyakan nama suaminya. Konsep tau mbale merupakan kata yang bersifat netral sehingga dapat dipahami bahwa pasangan suami istri memiliki posisi yang setara dalam rumah tangga. Kata tau mbale juga dapat bermakna lebih halus dalam menyebutkan pasangan jika dibandingkan dengan mengatakan salakiku 'suamiku' dan sawaiku 'istriku'.

Ditemukan sebuah ungkapan yang sering diajarkan oleh orang tua terhadap anak-anaknya. Ungkapan tersebut adalah tau sawai enti pamongka, tau salaki enti rangala 'perempuan memegang periuk nasi, laki-laki memegang alat bajak sawah'. Maksudnya adalah perempuan bekerja di dalam rumah mengurus rumah tangga, lelaki bekerja di sawah membajak sawah (bekerja di luar rumah). Hal tersebut menunjukkan bahwa orang-orang tua terdahulu seringkali menanamkan pada anak-anaknya bahwa pekerjaan perempuan adalah memasak dan mengurus segala urusan rumah tangga dan lelaki bekerja mencari nafkah di luar rumah.

Ungkapan tau sawai enti pamongka, tau salaki enti rangala menunjuk pada pembagian tugas antara laki-laki dan perempuan dalam masyarakat Samawa. Ungkapan tersebut menyiratkan perempuan bekerja di dapur memasak dan lakilaki bekerja membajak sawah. Kenyataan dalam masyarakat suku Samawa bahwa perempuan tidak hanya bertugas memasak di dapur akan tetapi banyak juga perempuan yang bekerja di sawah. Perempuan menanam padi di sawah, merawat 
dan ikut pula bekerja saat memanen padi atau hasil pertanian lainnya. Jadi, ungkapan tersebut sebenarnya telah sejak lama dipatahkan oleh masyarakatnya sendiri, terbukti bahwa perempuan juga sibuk bekerja di sawah dan ladang mereka bahkan mengambil upah untuk bekerja di sawah dan ladang orang lain. Belakangan konsep ini sudah mulai memudar karena banyak perempuan yang mengikuti perkembangan zaman dan kemajuan teknologi sehingga banyak perempuan yang bekarja di ranah publik.

Ungkapan tau salaki balemar, tau sawai basowan 'lelaki memikul di pundak, perempuan menjunjung di kepala'. Maksud dari ungkapan tersebut adalah tentang beban kerja jumlah barang yang harus dibawa oleh lelaki dan perempuan. Ungkapan tersebut menunjukkan bahwa barang bawaan laki-laki lebih berat dari barang yang di bawa oleh perempuan. Ungkapan tersebut sebenarnya berkaitan dengan pembagian warisan dalam agama Islam. Mayoritas masyarakat suku Samawa merupakan pemeluk agama Islam sehingga ungkapan tersebut dapat dijadikan sebagai pedoman dalam pembagian warisan bagi anak laki-laki dan anak perempuan.

Ungkapan basawai dunung sanopoka basawai 'menikahlah dahulu sebelum menikah'. Sebenarnya ungkapan tersebut belum tepat jika diartikan demikian karena maksud sesungguhnya dari ungkapan tersebut adalah ajaran terhadap taruna 'jejaka' Samawa agar menyiapkan segala sesuatu terlebih dahulu sebelum benar-benar melaksanakan pernikahan. Lelaki akan memiliki tanggung jawab yang besar terhadap keluarganya. Lelaki tidak hanya harus bersiap secara materi untuk melangsungkan pernikahan, tetapi lelaki harus bersiap secara mental dalam menjalani pernikahan karena lelaki akan bertanggung jawab atas seorang perempuan yang menjadi istri juga bertanggung jawab atas anak-anak yang kelak dilahirkan oleh istrinya. Seorang laki-laki yang akan menikah harus terlebih dahulu belajar banyak tentang kehidupan, memperdalam ilmu agama karena lakilaki adalah imam bagi keluarganya, belajar bermasyarakat, belajar untuk memenuhi kebutuhan hidup dan akan lebih baik jika memiliki pendidikan yang memadai. Jadi, ungkapan basawai dunung sanopoka basawai merupakan nasihat 
orang tua terhadap anak laki-lakinya yang hendak menikah untuk mempersiapkan diri terlebih dahulu sebelum menerima tanggung jawab besar dalam pernikahan.

Ungkapan berang uda api 'parang yang kurang perapian'. Parang yang kurang apinya akan mudah rusak dan cepat tumpul. Berang uda api merupakan simbol untuk mengatakan tentang seorang lelaki yang kurang nyali, kurang perkasa, kurang pengetahuan atau kurang pengalamannya sehingga dalam melakukan sesuatu selalu bergantung pada orang lain. Ungkapan ini juga biasa ditujukan pada laki-laki yang kurang berani dalam mendekati perempuan. Ungkapan ini juga ditujukan pada lelaki yang kemampuan seksualnya lemah sehingga dikatakan berang uda api. Jadi, berang (parang) merupakan simbol lelaki atau simbol keperkasaan lelaki.

Ungkapan mara bulan kapangan berarti bagaikan gerhana bulan. Bulan yang sedang gerhana menimbulkan kegelapan atau kesuraman cahaya. Bulan merupakan simbol seorang gadis. Apabila seorang gadis murung, sedang bersedih atau sedang sakit maka disimbolkan sebagai bulan kapangan (gerhana bulan). Jadi, bulan kapangan disimbolkan sebagai gadis yang sedang dirundung kesedihan sehingga cahaya (kecantikannya) menjadi berkurang atau redup.

\section{d. Tradisi Berperspektif Gender}

Hasil penelitian ditemukan tradisi berperspektif gender yang berlaku dalam masyarakat Samawa, yaitu tradisi tama lamung 'tradisi memakaikan baju' (hanya untuk perempuan); barodak 'membersihkan tubuh dengan lulur' (untuk laki-laki dan perempuan); tama kengkam/bakengkam 'dipingit' (untuk laki-laki dan perempuan); dan jit awi lompo 'menjahit kain putih' (untuk laki-laki dan perempuan.

Tradisi tama lamung dilaksanakan oleh orang tua terhadap anak perempuan yang mulai beranjak remaja. Tradisi tama lamung menandai bahwa seorang anak perempuan sudah beranjak remaja sehingga diharapkan dia mampu menjaga harkat dan martabatnya sebagai perempuan. Tradisi ini dilakukan pada anak yang beranjak remaja, namun saat ini biasanya tradisi tama lamung ini dirangkaikan dengan kegiatan mengkhitan anak perempuan yang masih kecil. 
Hermansyah (2017:77) tradisi tama lamung ini merupakan penghormatan terhadap perempuan sekaligus upaya menjaga nilai moral dan etika agar perempuan Sumbawa dapat memegang teguh pendirian dan martabatnya sehingga memiliki rasa malu. Konsep ini relevan dengan budaya ilaq 'malu' yang menjadi salah satu pilar budaya Samawa.

Barodak merupakan salah satu rangkaian kegiatan adat perkawinan masyarakat Samawa sebelum calon pengantin ke pelaminan. Barodak adalah kegiatan luluran atau membersihkan tubuh calon pengantin baik laki-laki maupun perempuan dengan berbagai ramuan khas masyarakat Samawa agar terlihat rupawan. Barodak ini dilakukan pada tubuh calon pengantin perempuan (dan lakilaki) yang dilakukan oleh perempuan yang disebut ina odak.

Tradisi tama kengkam (bakengkam) merupakan kegiatan memingit calon pengantin perempuan maupun laki-laki yang sudah diodak agar keduanya tidak bisa bertemu. Mereka dipingit oleh keluarganya masing-masing agar terhindar dari perbuatan yang tidak diinginkan atau agar tidak melanggar nilai-nilai agama. Tama kengkam ini biasanya dilakukan minimal seminggu sebelum akad nikah dilangsungkan.

Tradisi jit awi lompo merupakan tradisi menjahit kain berwarna putih yang biasanya dilakukan oleh beberapa orang perempuan yang dituakan di dalam masyarakat Samawa. Setelah awi lompo tersebut jadi (berbentuk sarung) yang dikenakan pada anak taruna maupun anak dadara. Awi Lompo merupakan kain warna putih yang telah dijahit berbentuk sarung dan dikenakan kepada anak gadis maupun jejaka. Awi lompo melambangkan kesucian bagi perempuan dan lambang keperjakaan bagi laki-laki. Biasanya awi lompo dibuat menjelang seorang gadis dan perjaka memasuki bahtera pernikahan. Hal tersebut melambangkan kesucian diri dan hati kedua mempelai. Jadi, kesucian diri dan kesucian hati tidak hanya harus dimiliki oleh seorang perempuan Samawa melainkan juga harus pula dimiliki oleh lelaki Samawa. 


\section{E. SIMPULAN}

Berdasarkan uraian di atas dapat disimpulkan bahwa perempuan Samawa sangat dihargai kedudukannya oleh masyarakatnya. Kaum lelaki memahami tentang bagaimana seharusnya mereka memperlakukan perempuan. Jika dilihat berdasarkan wujud kebahasaan berupa kata, gabungan kata, istilah, ungkapan dan tradisi-tradisi yang berlaku di dalam masyarakat Suku Samawa menunjukkan bahwa sikap dan perlakuan serta pandangan masyarakat lebih menyadari dan memahami bahwa kesetaraan gender di dalam masyarakat suku Samawa telah ada dan berlaku di dalam masyarakatnya.

\section{DAFTAR PUSTAKA}

Duranti, Alessandro. 1997. Linguistic Anthropology. London: Cambridge University Press.

Fakih, Mansour. 1996. Analisis Gender dan Transformasi Sosial. Yogyakarta: Pustaka Pelajar.

Foley, William A. 2001. Anthropological Linguistics: An Introduction. Malden, USA: Blackwell Publishers Inc.

Hermansyah, Wawan. 2017. "Terminologi Rumah Adat Sumbawa: Sebuah Tinjauan Antropolinguistik". Program Magister Pendidikan Bahasa Indonesia, Universitas Mataram.

Iswary, Ery. 2009. Simbolisme Jender dalam Folklor Makassar (Pendekatan Antropologi Linguistik). Linguistik Indonesia. Tahun ke 27 Nomor 1, Februari 2009.

Mahmud, Murni. 2009. Bahasa dan Gender dalam Masyarakat Bugis. Makassar: Pustaka Refleksi.

Mahsun. 2014. Metode Penelitian Bahasa: Tahapan Strategi, Metode, dan Tekniknya. Jakarta: Rajawali Pers.

. 2017 (Edisi Ketiga). Metode Penelitian Bahasa: Tahapan Strategi, Metode, dan Tekniknya. Jakarta: Rajawali Pers.

Sibarani, Robert. 2004. Antropolinguistik. Medan: Penerbit Poda.

Sibarani, Robert. 2013. "Pendekatan Antropolinguistik dalam Menggali Kearifan Lokal sebagai Identitas Bangsa". Prosiding. Makalah disajikan pada International Conference on Indonesian Studies dengan tema "Ethnicity and Globalitation" dilaksanakan tanggal 13-14 Juni 2013 yang 
diselenggarakan oleh Fakultas Ilmu Pengetahuan Budaya Universitas Indonesia di Yogyakarta.

. 2015. Pendekatan Antropolinguistik Terhadap Kajian Tradisi Lisan. Retorika: Jurnal Ilmu Bahasa. Volume 1 (1) April 2015.

Tim Pengumpul Ama Samawa. 2003. Hasil Pengumpulan Ama Samawa. Sumbawa: Pemerintah Kabupaten Sumbawa, Dinas Pendidikan Nasional.

Yunhadi, Wuwuh. 2016. Realitas Bahasa dalam Postulat Sapir dan Whorf. Lingua. Vol. 13 (2) September 2016.

Zulkarnaen, Aries. 2011. Kepemimpinan dalam Adat dan Rappang Tana Samawa. Yogyakarta: Penerbit Ombak. 